\title{
Pteridophyte Flora of Manaslu Conservation Area, Central Nepal
}

\author{
Shreehari Bhattarai*, Sangeeta Rajbhandary \\ Central Department of Botany, Tribhuvan University, Kathmandu, Nepal \\ Email: *sbsharma2010@yahoo.com
}

How to cite this paper: Bhattarai, S. and Rajbhandary, S. (2017) Pteridophyte Flora of Manaslu Conservation Area, Central Nepal. American Journal of Plant Sciences, 8, 680-687.

https://doi.org/10.4236/ajps.2017.84047

Received: October 1, 2016

Accepted: March 6, 2017

Published: March 9, 2017

Copyright (C) 2017 by authors and Scientific Research Publishing Inc. This work is licensed under the Creative Commons Attribution International License (CC BY 4.0).

http://creativecommons.org/licenses/by/4.0/

\begin{abstract}
The pteridophytes comprising ferns and fern allies constitute an important part in Nepalese flora. Pteridophyte flora of the Himalayan region is considered to be the basic requirements for the knowledge of pteridology. This paper aims to provide the overview of fern and fern allies present in the Nubri valley and its adjoining areas of Manaslu Conservation Area (MCA), Central Nepal. A total of 105 species belonging to 45 genera were recorded, with Dryopteris as the largest genera including twelve species followed by Athyrium, Pteris and Polystichum. With regard to habitats, most of the species were terrestrials followed by lithophytes and epiphytes.
\end{abstract}

\section{Keywords}

Pteridophytes, Manaslu Conservation Area, Habitat

\section{Introduction}

The pteridophytes comprising ferns and fern allies constitute an important part in Nepalese flora. Pteridophyte flora of the Himalayan region is considered to be the basic requirements for the knowledge of pteridology [1]. Nepal, though being small in area, is rich in biodiversity. This is because of high variable climate and mountainous habitat creating microclimates. As a result, 534 species of pteridophytes comprising 102 genera belonging to 35 families have been reported from Nepal [2]. However, according to recent information, there exist some 567 species and subspecies of pteridophytes [3].

The pioneer plant-exploration and taxonomic study on Nepalese pteridophytes, along with other groups of plants, started since the work of British botanists. The first collections of pteridophytes from Nepal came about at the beginning of the $19^{\text {th }}$ Century when the famous botanist Francis Buchanan (later Francis Hamilton) made collection in 1802-03 in the Kathmandu Valley. Although the collection of Nepalese pteridophytes started earlier, the taxonomic and biogeographic 
study started since David Don when he published a book Prodromus florae Nepalensis in 1825 [4] consisting of some 87 pteridophytes mainly based on collection made by Hamilton and Wallich, being the first ever treatment on Himalayan pteridophytes [2]. The pteridophyte flora are one of the least explored and documented group of plants in Nepal though used widely since prehistoric time. In this scenario, the present study aims to provide the overview of fern and fern allies present in the Nubri valley and its adjoining areas of Manaslu Conservation Area (MCA), Central Nepal (Figure 1, Figure 2).

\section{Materials and Methods}

\subsection{Study Area}

Manaslu Conservation Area (MCA), declared on December 28, is a mountainous region in the northern part of Gorkha district covers $1663 \mathrm{sq}$. km. with 7 VDCs viz. Samagaun, Lho, Prok, Bihi, Sirdibas, Chumchet and Chhekampar extending between $28^{\circ} 21^{\prime}$ to $28^{\circ} 45^{\prime}$ latitude and $84^{\circ} 30^{\prime}$ to $85^{\circ} 12^{\prime}$ longitude and

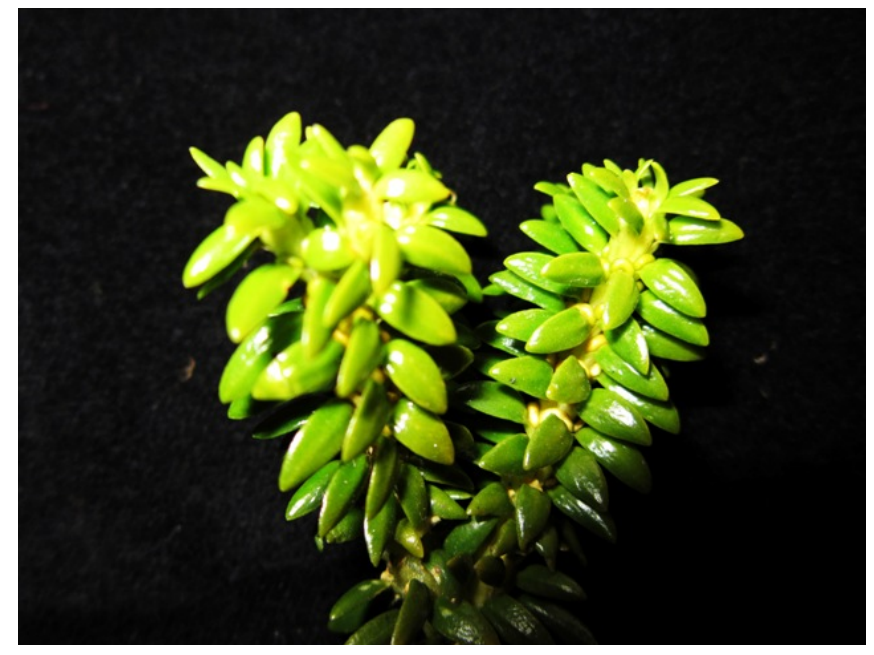

Figure 1. Huperzia hamiltonii (Spreng.) Trevis.

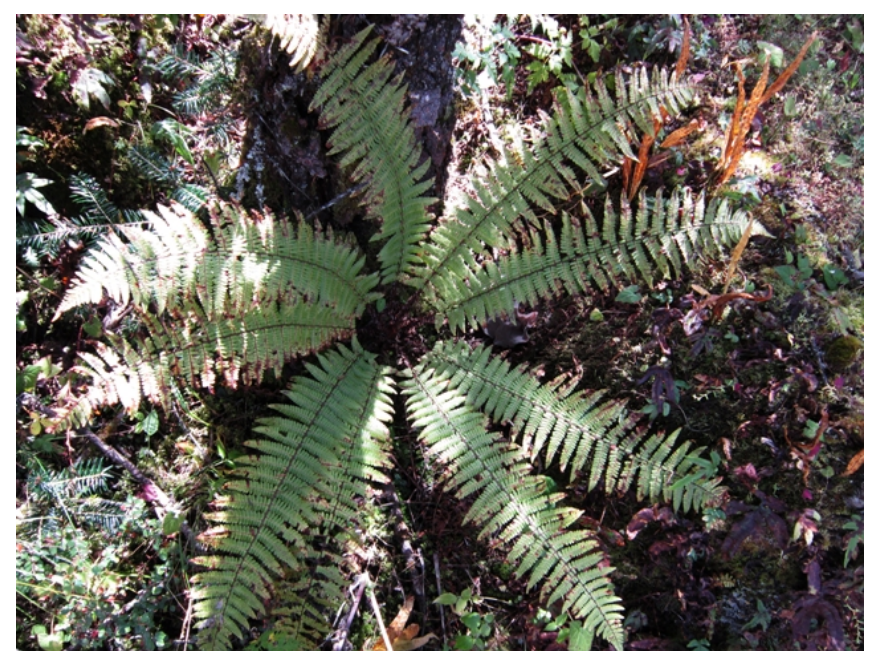

Figure 2. Dryopteris redactopinnata S. K. Basu \& Panigrahi. 
ranging from $1400 \mathrm{~m}$ (Jagat) to $8163 \mathrm{~m}$ (Mt. Manaslu) altitude. MCA is situated in the northern part of Gorkha district bordering with the Tibetan plateau of the people's republic of China to the north-east, Annapurna Conservation Area to the west and mid part of Gorkha district to the south. The altitudinal variation (1400-8163 $\mathrm{m}$ asl) has provided various micro climatic habitat that offer shelter to unique biodiversity. The collection points of specimens are shown with dots in the map of study area (Figure 3).

Vegetation of the study area was quite distinct from low $($ c. $1500 \mathrm{~m})$ to high altitudes $(4000 \mathrm{~m})$ ranging from farm-land $(\mathrm{c} .1500 \mathrm{~m})$ to almost alpine meadow (4000 m) including various forest types like Laurels, Picea, Larix, Quercus, Pinus, Rhododendron, Acer, Juniperus and Birch as dominating species with other associated species.

\subsection{Field Visit to the Study Area}

The field was visited twice pre and post-monsoon in 2012. First visit was on May-June and second Sept-Oct. to cover both major growing and flourishing seasons. The species immature in pre monsoon season were well flourished in post monsoon season so maximum information about the species could be
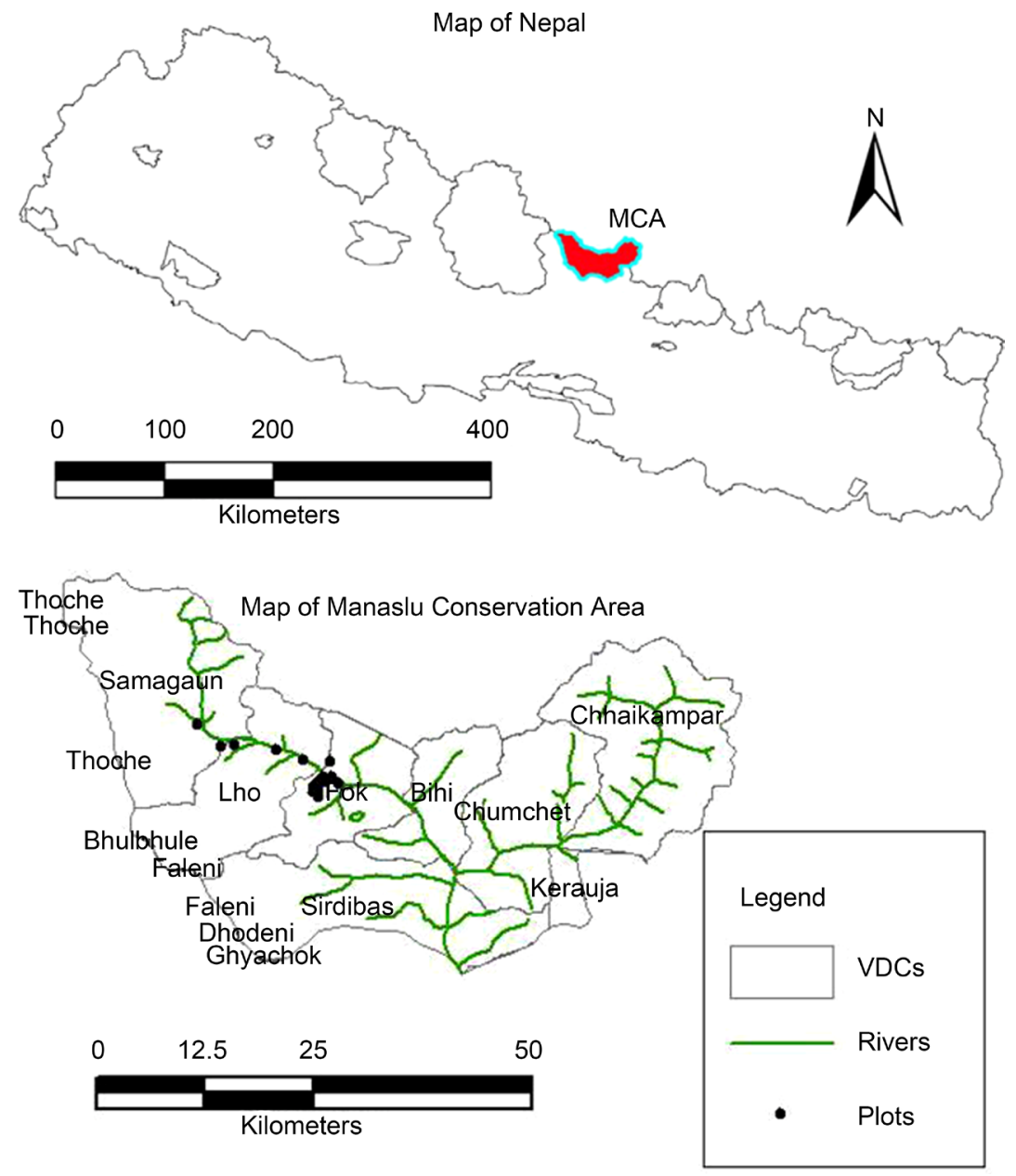

Figure 3. Study area represented by dots. 
gathered.

\subsection{Collection and Preparation of Herbarium}

Mature and healthy plants were selected for herbarium. The specimens were collected with rhizome, hairs and/or scales and fertile portion as far as possible. Before collecting the plant, all the information like color of fertile parts and their arrangement in natural habitat were noted down. The specimens were collected in polythene bags and pressed in herbarium press as soon as possible. Photographs of the specimens were taken in their natural habitat and immediately after collecting from the habitat to examine the sori and scales as well. Photographs were very much useful in delimiting the taxa especially at species level. The plant specimens were dried form the same day of preparation. For pteridophyte specimens simple drying was enough just by properly pressing, regularly checking the specimens during drying and changing paper to obtain neat and clean herbarium. The dried specimens were then mounted on the herbarium sheet and deposited at KATH.

\subsection{Identification}

Specimens collected from the field were identified for us by C. R. Fraser-Jenkins, a well-known specialist in Himalayan pteridophytes. We then referred to available literature on the subject including Beddome [5] [6] [7], DPR [8], Clarke [9], Iwatsuki [10], Gurung [1]; Khullar [11] [12], Borthakur et al. [13], DPR [2], Fraser-Jenkins [14], Fraser-Jenkins [15] etc. Some specimens were also compared with specimens deposited at TUCH \& KATH.

\section{Results}

A total no. of one hundred five (105) species of pteridophytes belonging to twenty (19) families and forty-five (45) genera were recorded. Among the twenty families, Polypodiaceae was the largest family with eight genera followed by Pteridaceae and Woodsiaceae each having six genera, Dryopteridaceae with five genera and Dennstaedtiaceae with three genera, while many other families were monotypic as in Figure 4.

Among the total forty-five genera, Dryopteris was the largest genera with twelve species followed by Athyrium with ten species. Other large genera are Polystichum and Pteris with six species each, followed by Lepisorus and Asplenium (five species each), Polypodiodes (four species), Adiantum, Cheilanthes, Notholaena, Pichisermollia, and Selaginella (three species each), Araiostegia, Botrychium, Coniogramme, Deparia, Diplazium, Drynaria, Onychium, and Thelypteris (two species each), while rest of the genera are monotypic or containing only one species each.

\section{Discussion \& Conclusion}

Manaslu Conservation Area (MCA), in Central Nepal provides a unique habitat for both flowering and non-flowering plants. A total of 105 species of 


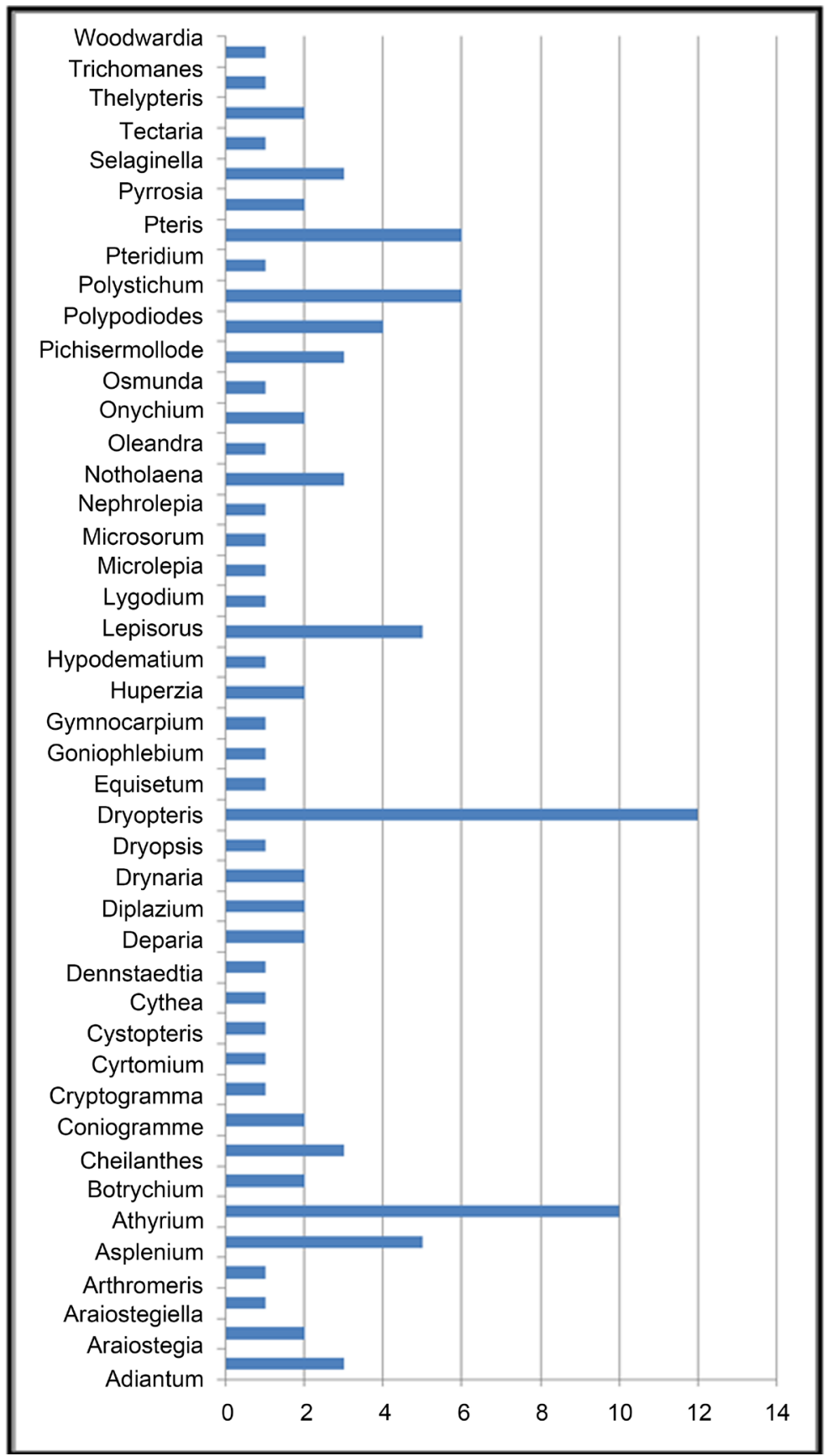

Figure 4. Number of species per genera.

pteridophytes belonging to 45 genera and 20 families have been found in the study area. Among 45 genera, Dryopteris is the largest genera with twelve species followed by Athyrium with ten species, Pteris and Polystichum each with six species, Asplenium with five species and Polypodiodes with four species. While, most of the genera like Araiostegiella, Arthromeris, Cryptogramma, Cythea, Equisetum, Goniophlebium etc. are monotypic.

\subsection{Distribution of Species Based on Habitat Types}

From the present study, the pteridophytes based on the habitat where they were 
found either growing on other plant, on land or on rocks have been broadly categorized into three major habitats viz. terrestrial, epiphytic and lithophytes. However, a few species were found flourish well in more than one distinct habitat.

Of the total 105 species collected, majority of the species i.e. 65 species were terrestrial, 34 species lithophytes and 28 species as epiphytic. Most of these terrestrial species were also recorded from similar habitats as described by Gurung [1] and Iwatsuki [9]. Some 12 species like Araiostegia pulchara, Araiostegia beddomii, Araiostegiella hookeri, Asplenium ensiformis, both species of Drynaria, Huperzia hamiltonii, Lepisorus loriformis both species of Pyrrosia, and Trichomanes latealatum are pure epiphytic i.e. growing usually on the mossy tree trunks and branches of trees or shrubs both in open and shaded places. Similarly, about 13 species viz. Arthromeris wallichiana, Athyrium davidii, Athyrium rupicola, Cheilanthes grisea, Cryptogramma brunoniana, Dryopteris acutodenta, Dryopteris chrysocoma, Dryopteris cochleata, Lepisorus clathratus, Adiantum tibeticum, Polystichum mehrae, Polystichum stimulans, Polystichum thomsonii and Pteris dactylina are found well flourished on rocky habitats (Figure 5).

Besides the species growing on distinct habitats, some species like Nephrolepis cordifolia is both terrestrial as well as epiphytes. While, there are other species found growing in more than one habitat as some 16 species Asplenium laciniatum subsp. kukkonenii, Asplenium laciniatum subsp. tenuicaule, Goniophlebium argutum, Lepisorus mehrae, Lepisorus scolopendrium, Lepisorus thunbergianus, Microsorum membranaceum, Oleandra wallichii, Pichisermollia ebinepes, Pichisermollia malacodon, Pichisermollia nigrovenia, Pichisermollia subebenipes, Polypodiodes microrhizoma, Polypodiodes amoena, Polypodiodes hendersonii, Asplenium yoshinagae subsp. indicum are growing both as epiphytes and lithophytes whereas Adiantum capillus-veneris, Nephrolepis cordifolia, Polystichum prescottianum and Tectaria coadunate are growing in terrestrial and as lithophytes.

\subsection{Economic Importance}

Since prehistoric times, people have been depending on nature, especially on

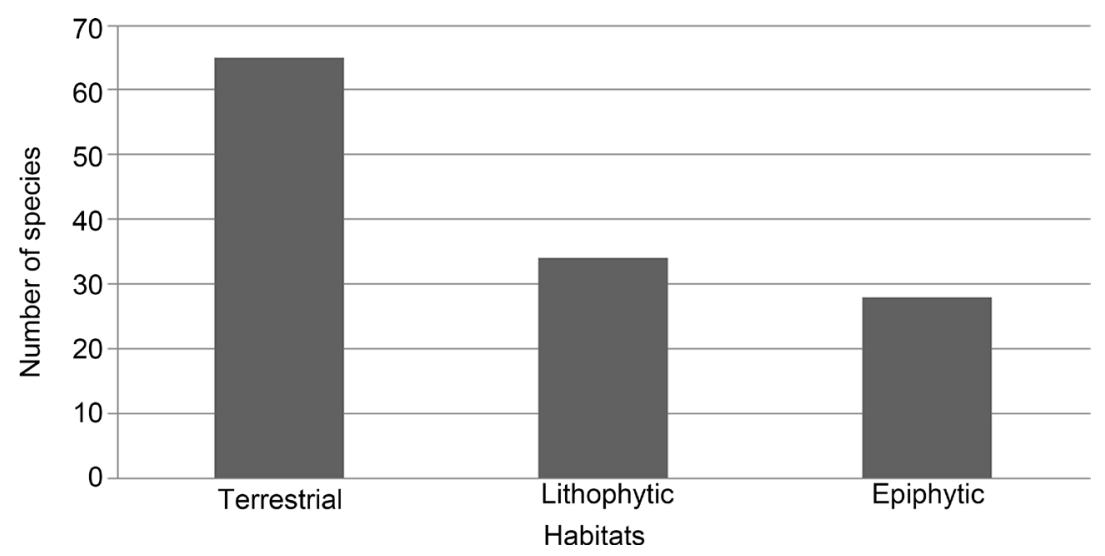

Figure 5. Diversity of ferns and fern allies with regards to habitats. 
plants, to sustain their basic needs. Pteridophytes are well known and widely used as ornamental, decorative, food, medicine and other common uses. The attractive ferns have been used in decoration of gardens, popularly called as "Pteris garden”, public parks, super stores, buildings and houses as well. In the present study too, many ferns are directly linked with daily life of the local people. The immature shoot of species like Diplazium esculentum, Tectaria coadunata, Dryopteris cochleata, Cythea spinulosa and water ball of Nephrolepis cordifolia are used for food. Of them, Diplazium esculentum is the most widely used species for vegetable and sustains livelihood of some locals. Similarly, rhizome of Drynaria spp. is another major source of income for local people. Huge amount of dried rhizome of Drynaria spp. is exported to Tibet. Another species used frequently for medicine is Pteris subquinata for cut and wound. Beside these food and medicine values, there are other species using for different purposes. Nephrolepis cordifolia and Drynaria spp. are frequently used for decoration. Gurung [1] has also reported these ferns being used for ornamental purposes in other parts of the country.

As agriculture being the major occupation of local people, lots of species like Dennstaedtia appendiculata, Pteridium revolutum, Pteris biaurita, Pteris cretica, Osmunda claytoniana, Dryopteris redactopinnata, Dryopteris sublacara, Athyrium, Diplazium maximum, Onychium contiguum, Coniogramme, Deparia and Woodwardia are mainly used for fodder and litter for animals and making green manure. Based on these uses, personal communication and information gathered from the field, ferns and fern allies of this area are entirely linked with the livelihood of local people and are economically important.

\section{Acknowledgements}

We are very grateful to Prof. Dr. K. K. Shrestha [16], Dr. C. B. Baniya, C. R. Fraser-Jenkins, J. P. Gajurel, R. Tamang, T. B. Chongbang, A. Thakali, R. Thapa, KATH, TUCH and NTNC-MCAP. We are thankful to University Grant Commission, Nepal for providing financial support.

\section{References}

[1] Gurung, V.L. (1991) Ferns the Beauty of Nepalese Flora. Sahayogi Press, Kathmandu.

[2] DPR (2002) Pteridophytes of Nepal. Bull. Dept. Plants 19. HMG, Nepal.

[3] Fraser-Jenkins, C.R., Pariyar, S. and Kandel, D.R. (2014) An Annotated Checklist of the Pteridophytes of Nepal-Baseline for the Flora of Nepal (in Preparation).

[4] Don, D. (1825) Prodromus Florae Nepalensis: 1-256. Londinium. Reprinted 1976. Dehra Dun, Delhi.

[5] Beddome, R.H. (1865-70) The Ferns of British India 1 and 2. Thacker, Spink and Co., Madras.

[6] Beddome, R.H. (1883) Handbook to the Ferns of British India, Ceylon and the Malay Peninsula. Thacker Spink \& Co., Calcutta.

[7] Beddome, R.H. (1892) Supplement to the Ferns of British India, Ceylon and the Malay Peninsula. Thacker Spink \& Co., Calcutta. 
[8] DPR (1976) Flora of Langtang and Cross Section Vegetation Survey (Central Zone). Bull. Dept. Med. Plants 6. HMG, Nepal.

[9] Clarke, C.B. (1880) A Review of the Ferns of Northern India etc. Transactions of the Linnean Society of London, 1, 425-619.

[10] Iwatsuki, K. (1988) An Enumeration of the Pteridophytes of Nepal. In: Ohba, H. and Malla, S.B., Eds., The Himalaya Plants, University of Tokyo Press, Tokyo, 231339.

[11] Khullar, S.P. (1994) An Illustrated Fern Flora of West Himalaya. 1, Intrernationl Book Distributors, Dehra Dun.

[12] Khullar, S.P. (2000) An Illustrated Fern Flora of West Himalaya. 2, Intrernationl Book Distributors, Dehra Dun.

[13] Borthakur, S.K., Deka, P. and Nath, K.K. (2001) Illustrated Manual of Ferns of Assam. Bishen Singh Mahendra Pal Singh, Dehra Dun.

[14] Fraser-Jenkins, C.F. (2008) Taxonomic Revision of Three Hundred Indian Subcontinental Pteridophytes with a Revised Census-List. Bishen Singh Mahendra Pal Singh, Dehra Dun.

[15] Fraser-Jenkins, C.R. (2010) Nepal's Little Known Pteridophytes, the Hidden Work of David Don, and the Geography and Distribution of Indo-Himalayan Ferns with State Lists. Website Version, 1 December 2010, Updated 12 May 2011 and 4 October 2011. http://www.groups.yahoo.com/group/indian-ferns

[16] Bhagat, I.M. and Shrestha S. (2010) Ferns and Fern-Allies of Eastern Tarai, Nepal. Our Nature, No. 8.

Submit or recommend next manuscript to SCIRP and we will provide best service for you:

Accepting pre-submission inquiries through Email, Facebook, LinkedIn, Twitter, etc. A wide selection of journals (inclusive of 9 subjects, more than 200 journals)

Providing 24-hour high-quality service

User-friendly online submission system

Fair and swift peer-review system

Efficient typesetting and proofreading procedure

Display of the result of downloads and visits, as well as the number of cited articles

Maximum dissemination of your research work

Submit your manuscript at: http://papersubmission.scirp.org/

Or contact ajps@scirp.org 